\title{
PENERAPAN BISNIS MODEL KANVAS DALAM PENENTUAN RENCANA MANAJEMEN USAHA KEDELAI EDAMAME GORENG
} Implementation of Business Model Canvas in Determining on Plan Management of Fried Edamame Business

\author{
Novitha Herawati $^{1) *}$, Triana Lindriati ${ }^{1)}$, Ida Bagus Suryaningrat ${ }^{1)}$ \\ 1) Program Studi Magister Teknologi Agroindustri, Fakultas Teknologi Pertanian, Universitas Jember \\ Jl. Kalimantan 37, Kampus Bumi Tegalboto, Jember 68121 \\ *Korespondensi Penulis: pored.jember@gmail.com
}

\begin{abstract}
Business model canvas (BMC) is a strategic management and lean start-up template for developing new or documenting existing business models. It is a visual chart with elements describing a firm's or product's value proposition, infrastructure, customers, and finances. It assists firms in their aligning activities by illustrating potential trade-offs. Business model canvas focuses on the idea of creating value in a business. The purpose of implementation of BMC was to determined the best business planning of fried edamame, when it applied to the industry or MSMEs (Micro, Small and Medium Enterprises). The method in the research used descriptive method, while the data analysis used qualitative analysis. Primary data collection was obtained from interviews. Analysis was done by compiling the initial hypothesis, hypothesis testing and verification of business model canvas (BMC). The results showed that the business model strategy for fried edamame products in the value proposition component were crispy, natural, labeled and applied good cooking oil for use. The customer segment component were the buyers of the entire Jember Regency including men and women over 20 years old with middle income. Components of revenue streams were fried edamame product sales, sale of unused oil, and sale of edamame peel to farmers, while the component channels were direct selling and retailers for fried edamame product.
\end{abstract}

Keywords: business model, fried edamame, strategy, value proposition

\section{PENDAHULUAN}

Usaha mikro dan kecil tumbuh subur di Indonesia, ketika krisis moneter meluas menjadi krisis multi-dimensi yang menimpa Indonesia sejak tahun 1997. Krisis ini ternyata memotivasi pertumbuhan sektor usaha kecil yang semakin hari semakin menyerap tenaga kerja dan semakin memperkuat inovasiinovasi pengembangan usaha kecil. Hal tersebut dapat dilihat melalui perkembangan UMKM sepanjang tahun 2011 terbukti mampu berkontribusi dalam pembentukan PDB sebesar 57,60\% (Dinkop Prov. Jatim, 2013).

Makanan merupakan bidang yang paling banyak diminati, karena lebih mudah mencari pasarnya di Indonesia. Angka pertumbuhan ekonomi jawa Timur yang cukup fantastis mencapai 7,22 persen di akhir 2012 didongkrak oleh sektor UMKM (usaha mikro kecil dan menengah). Bahkan dari PDRB Jatim yang mampu mencapai Rp 1.000 triluin, sebesar 54 persennya diperoleh dari 4,2 juta UMKM yang tumbuh dan berkembang di Jatim (Dinkop Prov. Jatim, 2014).

Edamame goreng merupakan salah satu inovasi pengembangan produk pangan olahan edamame, memiliki cita rasa nikmat dan memiliki nutrisi yang tidak jauh beda dengan kondisi segarnya. Edamame goreng merupakan camilan ringan yang dapat dipasarkan lebih luas, lebih tahan lama, praktis, ekonomis dan lebih memuaskan konsumen.

Persaingan usaha yang sangat tinggi tentunya memacu semangat pelaku usaha untuk lebih meningkatkan produktivitas maupun sistem yang telah dimiliki. 
Persaingan bisnis semakin berat dan ketat, setiap perusahaan selalu dituntut untuk berkembang. Salah satu cara yang digunakan perusahaan atau pelaku usaha untuk dapat bersaing dan berkembang adalah menciptakan strategi - strategi yang baru. Namun strategi itu sendiri tidaklah cukup, perusahaan harus punya model bisnis yang kuat dan baik serta tepat pada perusahaan miliknya. Business model canvas (BMC) memiliki keunggulan dalam analisis model bisnis yaitu mampu mengambarkan secara sederhana dan menyeluruh terhadap kondisi suatu perusahaan saat ini berdasarkan segmen konsumen, value yang ditawarkan, jalur penawaran nilai, hubungan dengan pelangan, aliran pendapatan, aset vital, mitra kerja sama, serta struktur biaya yang dimiliki (Rainaldo et al., 2017).

Menurut penelitian yang telah dilakukan oleh Euis et al. (2014), business model canvas (BMC) memiliki sembilan elemen yang penting dalam membantu mengidentifikasikan model bisnis pada KNM Fish Farm dan membantu untuk mengidentifikasi elemen-elemen yang memerlukan perbaikan untuk membantu keberlangsungan usaha di masa depan. Bisnis model kanvas juga dapat digunakan sebagai alat untuk memberikan usulan rancangan model bisnis yang baru yang akan diterapkan salah satu unit usaha baru CV. OAG yang memproduksi keripik bayam (Rukka et al., 2018). Permadi et al. (2016) melaporkan bahwa melalui analisis BCM (business model canvas) pada CV. Kandura Keramik Bandung terdapat 7 program perbaikan yang disarankan meliputi pembentukan segmentasi, kerjasama perusahaan dan aktivis seni untuk membentuk komunitas keramik kontemporer, membentuk website pribadi, bekerjasama dengan rekanan pemasok, kurir, investor, serta tenaga ahli yang kompeten, mendaftarkan produk, membentuk subdivisi quality control dan teknik pewarnaan, serta merekrut SDM yang potensial.
Melihat prospek usaha makanan ringan ke depan yang cukup menjanjikan dan tingginya persaingan serta berbagai permasalahan yang dihadapi, maka perlu dilakukan penelitian model bisnis usaha edamame goreng. Tujuan perencanaan bisnis model kanvas adalah untuk mengetahui perencanaan model bisnis terbaik usaha edamame goreng apabila diterapkan sebagai teknologi tepat guna di industri atau UMKM (Usaha Mikro Kecil Menengah).

\section{METODE PENELITIAN}

\section{Alat dan Bahan}

Alat yang digunakan untuk penelitian yaitu kuisioner dan bebrapa alat pendukung dalam pengambilan data bisnis model kanvas. Bahan yang digunakan dalam penelitian yaitu edamame goreng dalam berbagai kemasan.

\section{Metode Penelitian}

Pada tahapan perencanaan bisnis model kanvas, beberapa hal yang harus dilakukan adalah menentukan hipotesis awal komponen-komponen dalam model bisnis kanvas untuk usaha edamame goreng. Komponen-komponen bisnis dalam model bisnis awal ini kemudian diuji kesesuaiannya sehingga diperoleh perubahan-perubahan untuk perbaikan komponen-komponen model bisnis kanvas berdasarkan masukan-masukan yang ada. Tahapan dalam perancangan komponenkomponen dalam model bisnis kanvas untuk produk edamame goreng setelah penyusunan hipotesis awal adalah pengujian hipotesis dan verifikasi model bisnis.

\section{Metode Pengolahan Data}

Pada penelitian ini metode yang dilakukan adalah metode deskriptif dengan pendekatan studi kasus. Metode penelitian deskriptif digunakan untuk memperoleh gambaran informasi, penjelasan, dan kondisi yang berkaitan 
dengan obyek penelitian secara faktual akurat dan sistematis. Metode yang dilakukan adalah dengan menggunakan pendekatan business model canvas melalui wawancara dan FGD (focus group discussion) yang dilakukan terhadap responden.

Langkah pertama yang dilakukan dalam model bisnis kanvas adalah membuat hipotesis awal kemudian dikonfirmasikan kepada konsumen secara langsung dan tidak langsung (on line). Konfirmasi dilakukan dengan test the problem dan test the solution kepada konsumen dan penjualan produk (Blank dan Dorf, 2012). Model bisnis kanvas terdiri dari sembilan komponen bisnis yang dapat dilihat pada Gambar 1.

Model bisnis kanvas memiliki komponen bisnis. Kesembilan komponen bisnis yang ada pada model bisnis kanvas adalah sebagai berikut (urut dari kanan ke kiri):

1. Customer segment (CS), yaitu menentukan segmen target customer dari produksi edamame goreng yang akan dikembangkan,

2. Value proposition (VP), yaitu memperkirakan kebutuhan customer yang sudah diidentifikasi pada customer segment,

3. Customer relationship (CR), yaitu mendefinisikan hubungan antara sektor usaha dengan customer,

4. Channel $(\mathrm{CH})$, yaitu suatu cara untuk mencapai customer,

5. Revenue stream (RS) yaitu representasi dari jalur penerimaan uang yang akan diterima dari setiap customer segment,

6. Key resource (KR) adalah sumber daya utama yang menjelaskan mengenai asset terpenting yang diperlukan dalam membuat model bisnis,

7. Key activities (KA) adalah kegiatan utama,

8. Key partners (KP) adalah kunci kemitraan yang menjelaskan jaringan pemasok dan mitra,

9. Cost structure (CR) adalah struktur biaya yang menggambarkan semua biaya yang dikeluarkan.

\section{Teknik Penentuan Narasumber}

Teknik penentuan narasumber yang digunakan adalah teknik purposive sampling yaitu dimana pengambilan sampel harus berdasarkan karakteristik tertentu yang merupakan ciri-ciri pokok

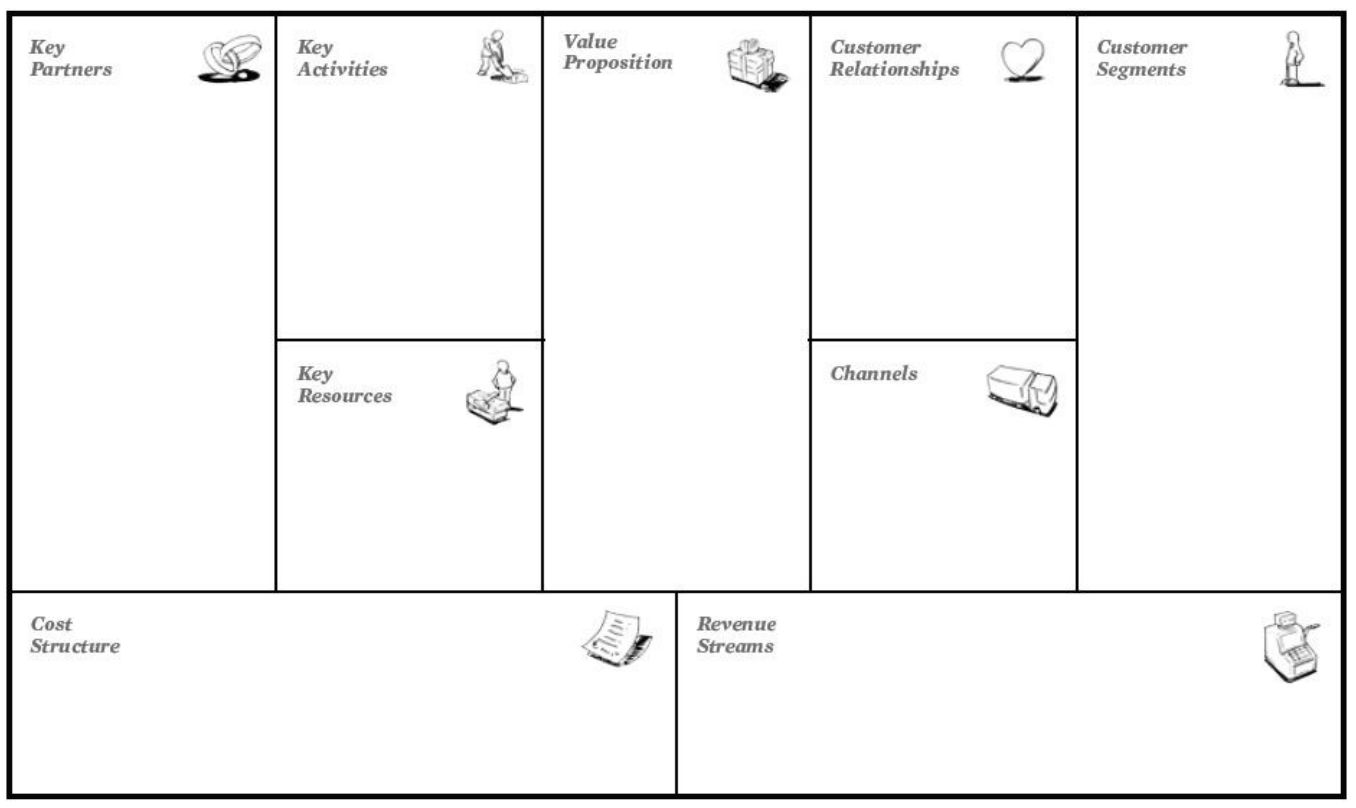

Gambar 1. Komponen bisnis pada model bisnis kanvas (Osterwalder et al., 2010). 
populasi, sehingga narasumber yang digunakan adalah customer produk edamame goreng. Survei langsung pada tahap ini menggunakan 50 calon konsumen potensial untuk menguji permasalahan dan pengujian solusi. Responden untuk pengujian masalah dan pengujian solusi terdiri dari 20 mahasiswa dan 30 orang dari kalangan umum. Hasil pengujian dituliskan dalam model bisnis kanvas 1 dan 2.

\section{Teknik Analisis Data}

Teknik analisis data yang digunakan dalam rencana penentuan bisnis edamame goreng mengacu pada teori dari Moleong (2012) yaitu:

1. Mengumpulkan semua data yang diperoleh dari berbagai sumber melalui wawancara.

2. Reduksi data, membuat abstraksi berupa rangkuman mengenai inti dari penelitian, proses, dan pernyataan yang sesuai dengan tujuan penelitian.

3. Kategorisasi di mana peneliti dituntut untuk menyusun data ke dalam kategori yang disusun berdasarkan pandangan, pendapat atau kriteria tertentu.

4. Pemeriksaan keabsahan data untuk menunjukkan bahwa isi data penelitian benar-benar asli atau valid dengan menggunakan teknik triangulasi di mana teknik ini menggunakan sesuatu yang lain selain data misalnya rekaman wawancara untuk menunjukkan atau

\section{Verifikasi Model Bisnis}

Verifikasi model bisnis kanvas dilakukan dengan cara penjualan produk kepada konsumen baik melalui retailer, online maupun secara langsung. Penjualan melalui retailer dilakukan pada pusat oleholeh di Kabupaten Jember dan retail yang potensial, sedangkan penjualan langsung kepada konsumen dari pengujian solusi, penjualan secara online dapat menggunakan media sosial seperti Facebook, Instagram, web, maupun toko online lainnya. Tempat penjualan produk edamame goreng adalah toko oleh-oleh Primadona 1, Primadona 2, Primadona Kampus, Cita Rasa, Sari rasa, Pia glenmore, Sumber Madu, Sari Madu, Pelangi sari, Toko Slamet Gajah Mada, Toko Slamet Armed, Koperasi Mitra Tani. Hasil verifikasi model bisnis dituliskan dalam komponen-komponen bisnis dalam model bisnis kanvas akhir.

\section{HASIL DAN PEMBAHASAN}

\section{Hipotesis Awal}

Hipotesis awal dilakukan sebelum konfirmasi kepada konsumen secara langsung dan tidak langsung. Hipotesis awal pada penelitian ini sebagai berikut:

\section{Customer Segment (CS)}

Segmen yang dipilih adalah seluruh lapisan masyarakat (unsegmented). Studi kasusnya adalah pada masyarakat di Kabupaten Jember.

\section{Value Proposition (VP)}

Value proposition produk edamame yang ingin diberikan adalah produk edamame goreng. Kriterianya adalah berkualis baik, tidak berminyak, tidak menimbulkan serik ketika dikonsumsi dan tanpa pengawet.

\section{Customer Relationship (CR)}

Customer relationship mencantumkan contact person untuk saran dan kritik sebagai bentuk layanan konsumen. Saran dan kritik akan digunakan untuk perbaikan selanjutnya.

4. Key Resource (KR)

Key resource untuk produk edamame goreng meliputi tiga hal utama yang penting. Hal utama tersebut yaitu bahan baku, peralatan, dan tenaga kerja.

\section{Channel $(\mathrm{CH})$}

Usaha edamame goreng chanel yang ingin digunakan, yaitu direct selling. Direct selling adalah penjualan langsung produk edamame goreng kepada masyarkat.

\section{Revenue Stream (RS)}

Revenue stream usaha edamame goreng yang ditargetkan adalah penjualan 
produk edamame goreng dan penjualan minyak yang tidak terpakai. Penjualan kulit edamame sebagai limbah produksi pada peternak juga dilakukan dalam rangka pemanfaatan limbah.

7. Key Activities (KA)

Aktivitas utama dalam usaha edamame goreng meliputi pembelian dan penyimpanan bahan baku, produksi, promosi, pemasaran, serta evaluasi dan pengembangan produk.

\section{Key Partners (KP)}

Key partners usaha edamame goreng meliputi strategic alliance between noncompetitors (perusahaan kemasan), buyer supplier relationship (Mitra Tani), dan perbankan. Key partners dengan pemerintah juga diperlukan dalam upaya untuk mendapatkan perizinan legalitas meliputi BPOM, SNI, dan barcode.

9. Cost Structure (CR)

Cost structure dalam usaha edamame goreng ini adalah biaya investasi, biaya tetap dan tidak tetap, biaya penyusutan, biaya pemeliharaan. Selain itu, angsuran kredit dalam menjalankan suatu usaha juga perlu dipehatikan.

\section{Pengujian Masalah (Test The Problem)}

Pengujian masalah bertujuan untuk mengetahui apakah hipotesis model bisnis yang dirancang sesuai dengan masalah yang dihadapi konsumen. Menurut Blank dan Dorf (2012) menjelaskan bahwa dalam tahap ini dilakukan survei langsung terhadap minimal 50 calon konsumen potensial untuk menguji permasalahan dalam model bisnis. Hasil kuesioner test the problem ditunjukkan pada Gambar 2.

Beberapa masalah yang kemungkinan dihadapi konsumen diuji kepada responden. Masalah yang diuji tentang minat pembelian edamame goreng, kealamian, dan tempat pembelian edamame goreng. Hasil survei menunjukkan bahwa $100 \%$ dari total responden pernah melihat produk edamame.

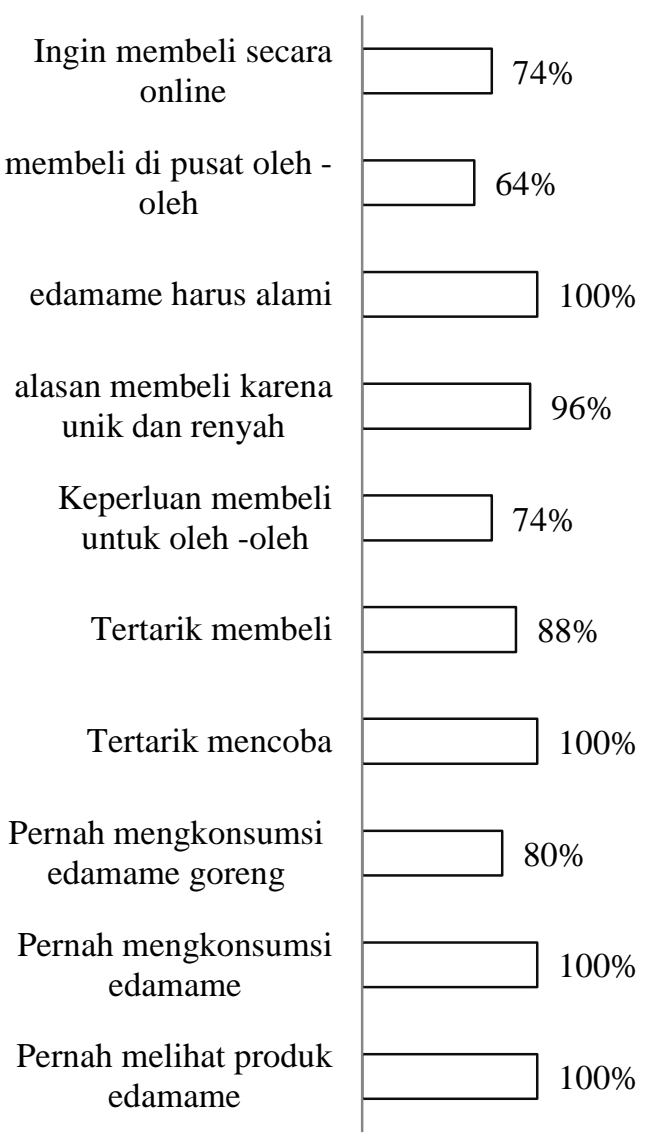

Gambar 2. Hasil kuisioner test the problem pada produk edamame goreng

Total responden $100 \%$ yang pernah mengkonsumsi edamame dan hanya $80 \%$ yang pernah mengkonsumsi edamame goreng. Selanjutnya dari total seluruh responden diketahui bahwa $100 \%$ tertarik untuk mencoba edamame goreng dan $88 \%$ tertarik untuk membelinya. Sebanyak $74 \%$ membeli edamame goreng untuk oleh-oleh, sedangkan sisanya lain-lain. Alasan responden tertarik membeli edamame goreng dikarenakan unik dan renyah sebanyak $96 \%$.

Berdasarkan $100 \%$ total responden diketahui setuju bahwa produk edamame goreng harus alami tanpa pewarna, tanpa pengawet dan perenyah. Sebanyak 64\% dari total responden bersedia membeli produk edamame goreng di retail (pusat oleh-oleh). Responden yang mau membeli 
produk edamame goreng secara on line $74 \%$.

survei untuk pengujian masalah mendorong untuk memperbaharui model bisnis awal (hipotesis). Pada komponen channels point penjualan on line (on line selling) ditambahkan dan point penjualan secara langsung (direct selling) dan retailer dapat dipertahankan. Pada komponen value proposition perlu ditambahkan point unik, renyah, dan aman dikonsumsi.

\section{Pengujian Solusi (Test The Solution)}

Pada tahap ini pengujian dilakukan dengan melakukan survei kembali kepada responden dengan menawarkan solusi dari hasil test the problem. Responden yang diuji tetap menggunakan responden yang sama pada test the problem (Blank dan Dorf, 2012). Hal ini dikarenakan semua responden yang digunakan tergolong konsumen yang potensial. Uji solusi ini ditujukan untuk menjawab masalah dan keinginan konsumen berdasar hasil pengujian masalah.

Berdasarkan hasil survei dari total 50 responden, $100 \%$ responden menyukai edamame goreng karena rasa gurih dan renyah. Seluruh responden setuju bahwa edamame goreng alami tanpa pengawet dan pewarna. Responden sebanyak $88 \%$ menyukai kemasan edamame goreng yang transparan berzipper lock dan berstiker, namun sisanya ingin kemasan yang lebih unik lagi. Hasil kuesioner test the solution ditunjukkan pada Gambar 3.

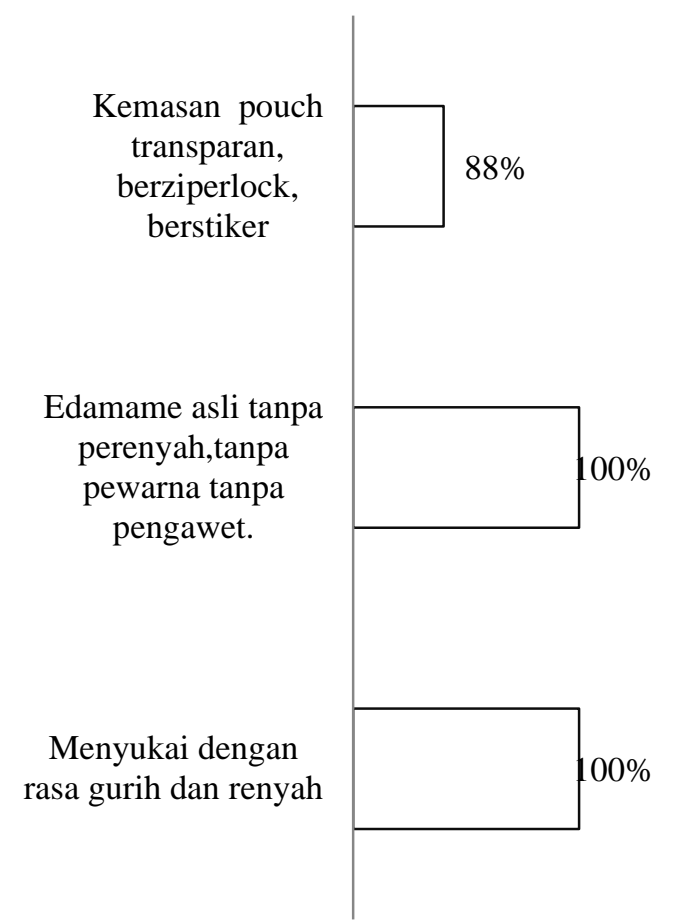

Gambar 3. Hasil kuisioner test the solution pada produk edamame goreng

Dari total responden sebanyak $82 \%$ tidak memberikan tanggapan atau saran dan sisanya memberikan saran yakni penggunaan minyak yang baik, harga yang terjangkau dan lainnya. Saran dari responden sebanyak $67 \%$ dari saran yang masuk menginginkan edamame goreng yang dijual memiliki harga yang terjangkau.

Berdasarkan hasil test the solution maka dilakukan perbaikan model bisnis kanvas yaitu pada komponen value proposition dengan menambahkan point kemasan berstiker dengan informasi yang jelas dan penggunaan minyak yang baik, berat produk bervariasi. Komponen value proposition dari test the problem pada model bisnis kanvas 1 tetap dipertahankan. Hasil selengkapnya tersaji dalam Gambar 4. 


\section{K.1 Model Bisnis Kanvas 0}

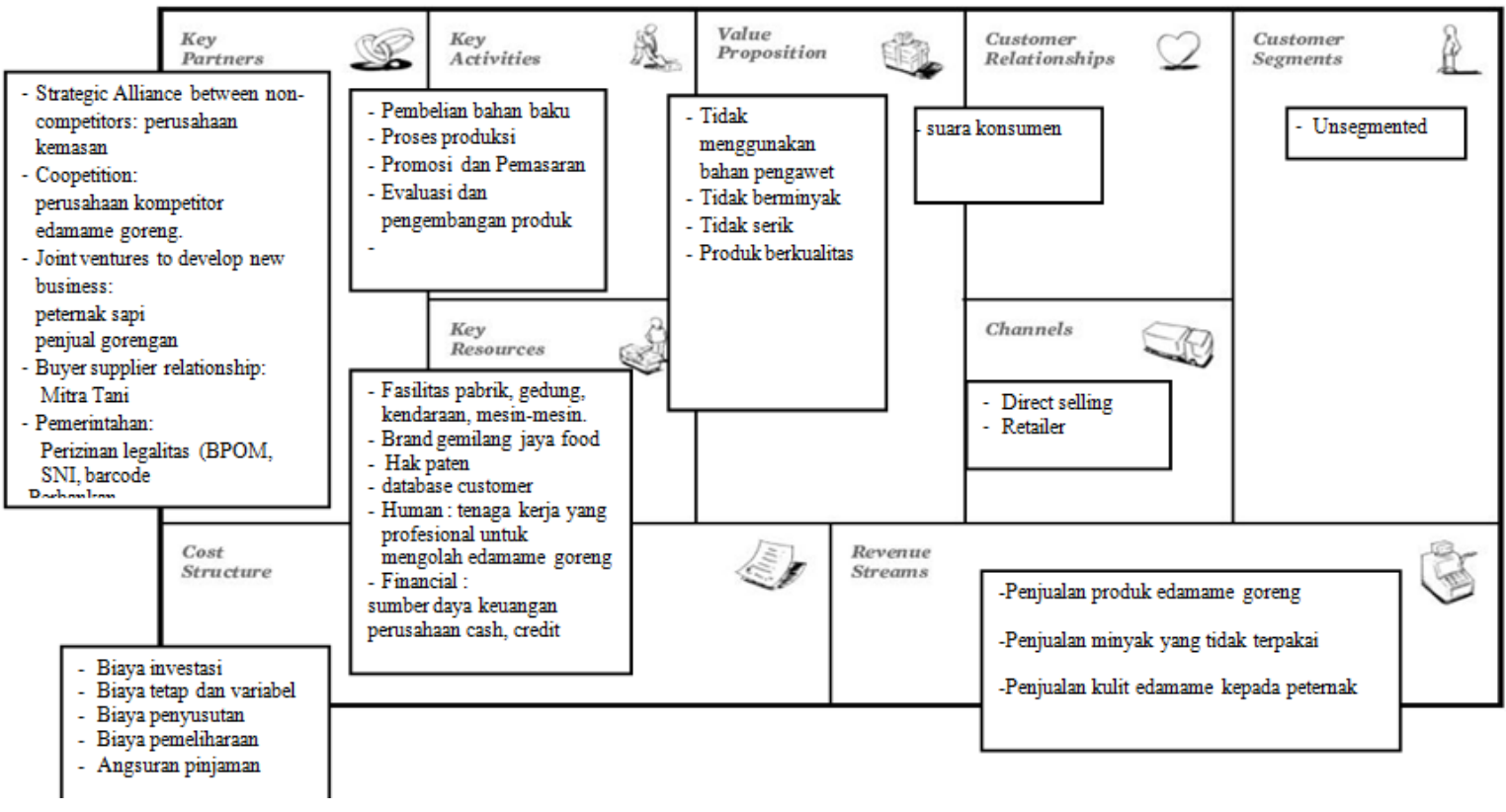

Gambar 4. Model bisnis hipotesis awal

\section{K.2 Model Bisnis Kanvas 1}

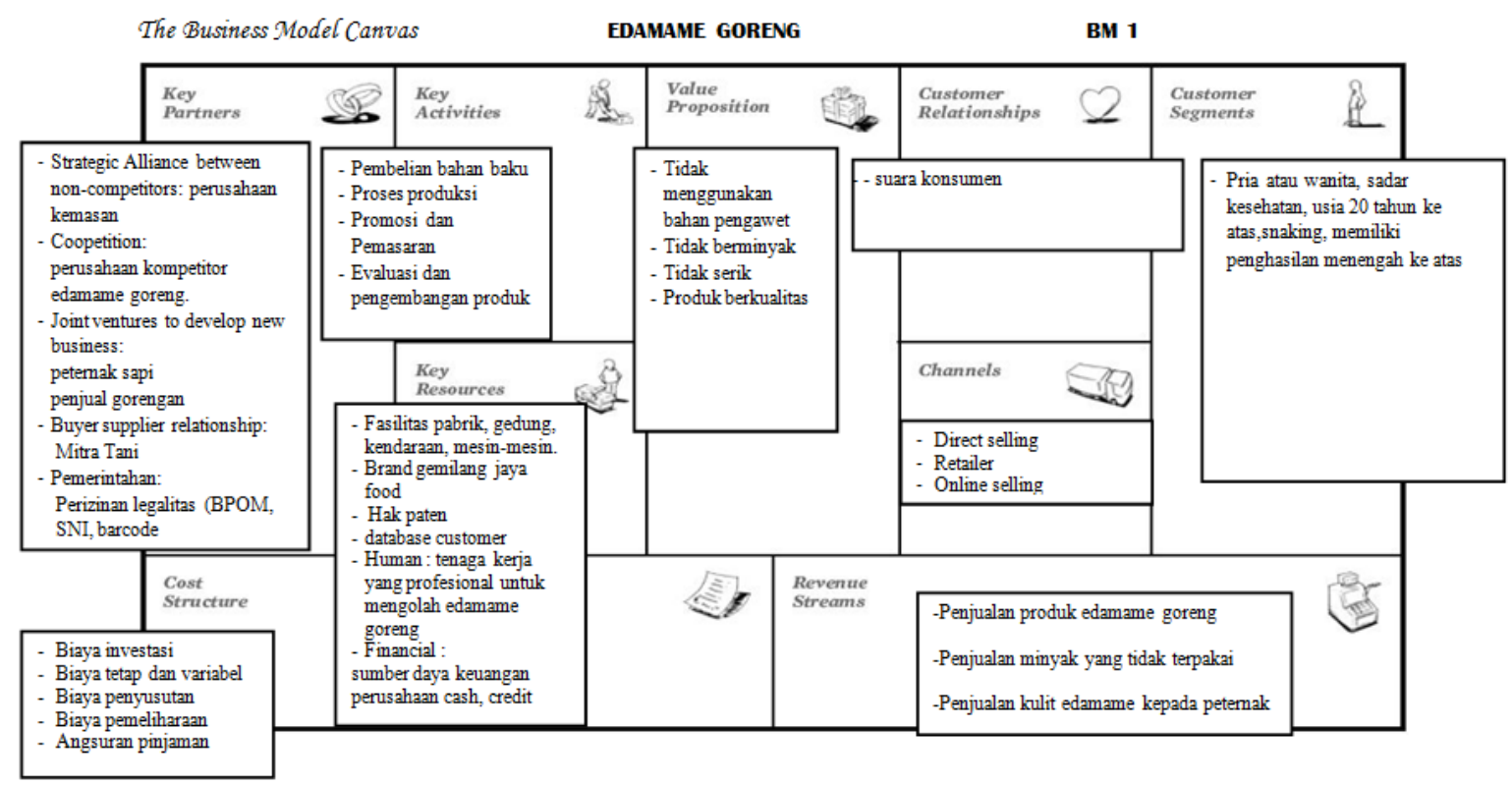

Gambar 5. Perbaikan model bisnis setelah survei

Model bisnis kanvas 0 (Gambar 4) merupakan model bisnis kanvas awal sesuai dengan sembilan komponen bisnis yang berasal dari data yang diperoleh hasil hipotesis awal. Selanjutnya dilakukan pengujian hipotesis dengan cara pengujian masalah (test the problem), pengujian solusi (test the solution), dan verifikasi model bisnis. Pengujian masalah dilakukan dengan melakukan survei langsung menggunakan kuisioner. Hasil yang diperoleh berdasarkan survei untuk pengujian masalah mendorong untuk memperbaharui komponen dalam model 
bisnis awal (hipotesis), sehingga diperoleh model bisnis kanvas 1 (Gambar 5).

Berdasarkan hasil test the solution maka dilakukan perbaikan komponenkomponen dalam model bisnis kanvas, sehingga diperoleh model bisnis kanvas 2
(Gambar 6). Tahapan terakhir dengan melakukan verifikasi model bisnis dengan menjual produk edamame goreng ke pasar. Data hasil verifikasi model bisnis dirangkai dan digunakan sebagai perbaikan komponen bisnis dalam kanvas

K.3 Model Bisnis Kanvas 2

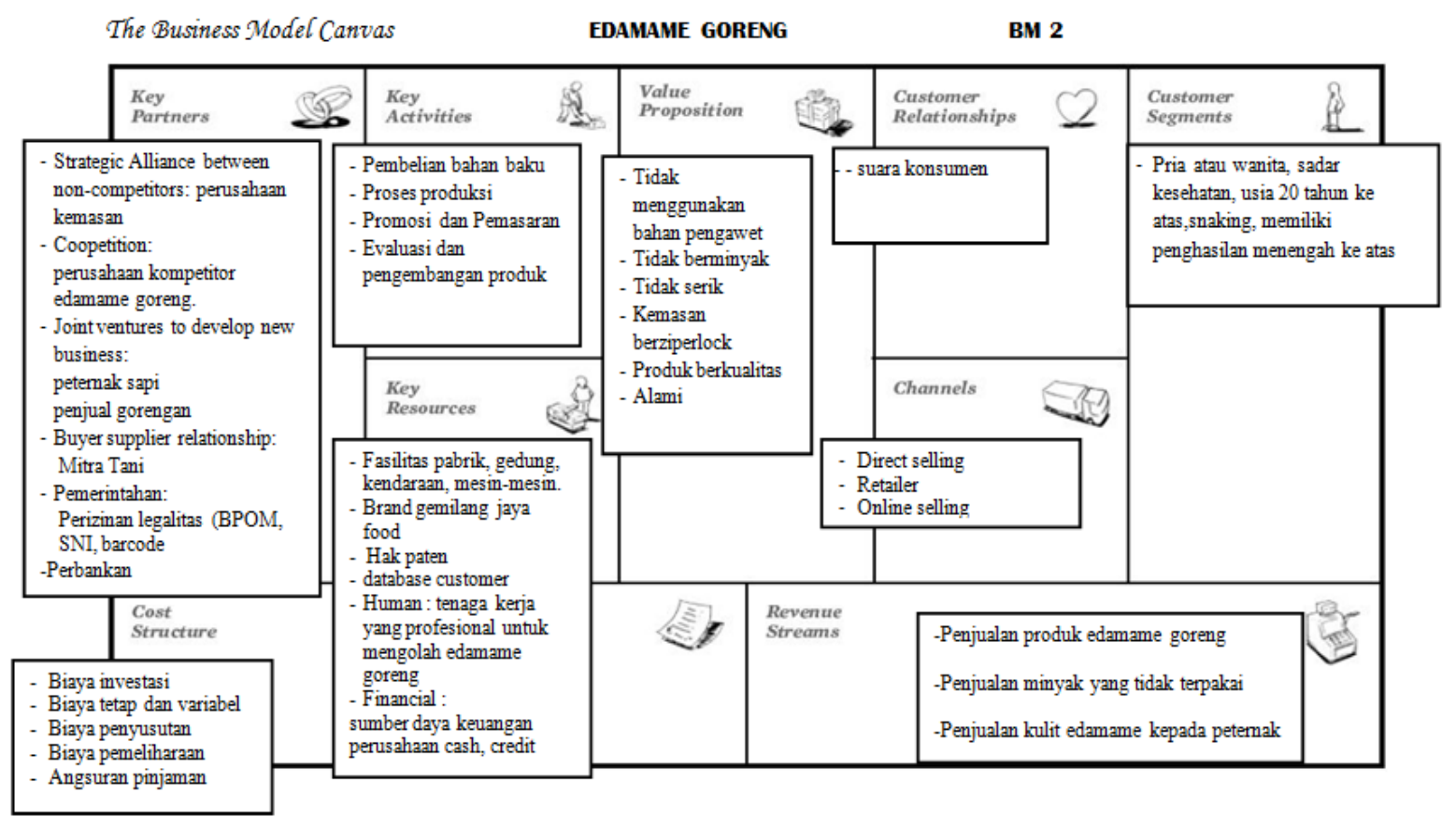

Gambar 6. Hasil BMC pada usaha edamame goreng setelah test the problem

\section{K.3 Model Bisnis Kanvas 3}

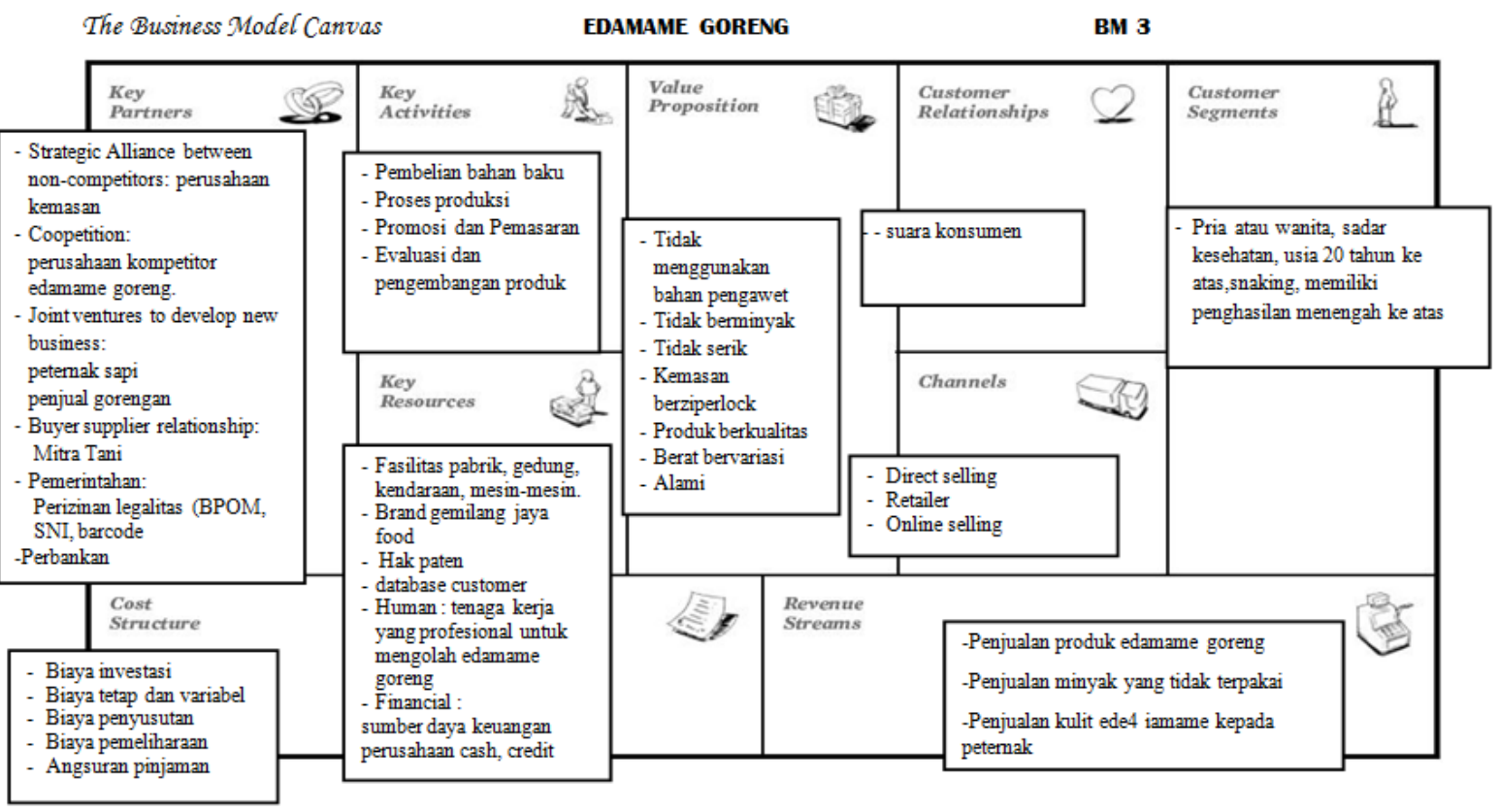

Gambar 7. Verifikasi model bisnis kanvas pada manajemen bisnis edamame goreng 
model bisnis yang sesuai dengan hasil verifikasi. Pada akhirnya diperoleh model bisnis kanvas 3 (Gambar 7).

\section{Verifikasi Model Bisnis}

Verifikasi dilakukan berdasarkan hasil pengujian masalah dan solusi. Verifikasi dilanjutkan dengan penyusunan model bisnis kanvas akhir. Pada tahap ini dilakukan verifikasi model bisnis dengan melihat data penjualan selama 2 tahun terakhir produk edamame goreng yang dipasarkan secara langsung maupun melalui retailer. Penjualan langsung dengan cara menjual langsung kepada calon konsumen yang potensial. Calon konsumen yang potensial dalam hal ini adalah teman, kolega, dan saudara. Retailer yang dimaksud adalah toko retail dan pusat oleh-oleh. Penjualan dilakukan selama kurang lebih 2 tahun terakhir pada awal bulan januari 2015 sampai akhir bulan Desember 2016.

Selama satu tahun terjual edamame goreng dengan ukuran $100 \mathrm{~g}$ sebanyak 5239 kemasan dan ukuran 200 g sebanyak 2463 kemasan, sedangkan di tahun ke 2 mengalami peningkatan permintaan dimana edamame kemasan $100 \mathrm{~g}$ laku terjual 6515 kemasan dan ukuran $200 \mathrm{~g}$ laku terjual 3034 kemasan. Penjualan edamame goreng terbagi menjadi dua kelompok penjualan. Kelompok pertama dijual di lingkungan umum, sedangkan kelompok kedua dijual secara langsung. Penjualan dilakukan di lingkungan Kabupaten Jember.

Berdasarkan data hasil penjualan edamame goreng selama 2 tahun terakhir diketahui bahwa terdapat penjualan $70 \%$ berasal dari retail dan $30 \%$ berasal dari penjualan langsung. Penjualan edamame goreng secara retail dengan kemasan berukuran $100 \mathrm{~g}$ adalah $36 \%$ penjualan dan $34 \%$ penjualan untuk kemasan berukuran $200 \mathrm{~g}$. Penjualan edamame goreng secara langsung dengan ukuran 100 g adalah $18 \%$ penjualan dan kemasan ukuran $200 \mathrm{~g}$ adalah $12 \%$ penjualan.
Persentase hasil penjualan edamame goreng ditunjukkan pada Gambar 8 . Penjualan tertinggi berasal dari penjualan retail. Oleh karenanya retail (toko oleholeh) merupakan tempat yang potensial untuk penjualan produk edamame goreng.

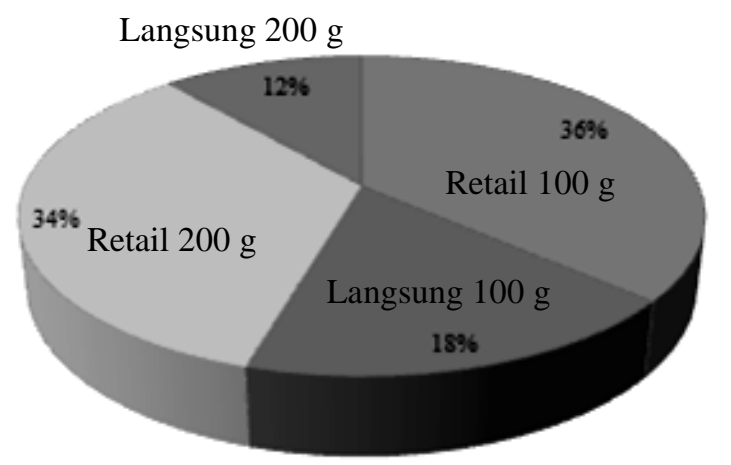

Gambar 8. Hasil penjualan edamame goreng meliputi penjualan langsung kemasan $100 \mathrm{~g}$ ( $\mathbf{\square})$, penjualan langsung kemasan $200 \mathrm{~g}(\square)$, penjualan retail kemasan $100 \mathrm{~g}(\square)$, penjualan retail kemasan $200 \mathrm{~g}(\square)$

Berdasarkan data hasil verifikasi model bisnis maka perlu dilakukan beberapa perbaikan dalam kanvas model bisnis. Pada komponen stream produk edamame goreng ditambahkan penjualan melalui online untuk memperluas penjualan. Selanjutnya pada komponen customer segment yang semula unsegmented diubah menjadi seluruh wilayah Jember, dewasa pria maupun wanita usia 20 tahun ke atas dan berpenghasilan menengah ke atas.

\section{KESIMPULAN}

Perencanaan model bisnis terbaik usaha edamame goreng terletak pada komponen value proposition pada model bisnis kanvas adalah renyah, alami, kemasan berstiker, dan penggunaan minyak goreng yang baik. Komponen customer segment adalah pembeli seluruh wilayah Kabupaten Jember, pria dan wanita pada rentang usia di atas 20 tahun dengan penghasilan menengah $\mathrm{ke}$ atas. Komponen revenue stream adalah 
penjualan produk edamame goreng, penjualan minyak yang tidak terpakai, penjualan kulit edamame kepada peternak. Selain itu, komponen channels yang digunakan pada usaha edamame goreng adalah direct selling dan retailer di lingkungan Kabupaten Jember.

\section{DAFTAR PUSTAKA}

Blank, S. dan Dorf, B. 2012. The Startup Owner's Manual TM The Step-by-Step Guide for Building a Great Company. K and $S$ Ranch Inc., K\&S Ranch Publishing Division, California.

Dinkop (Dinas Koperasi) Provinsi Jatim. 2013. Perkembangan Data Usaha Mikro, Kecil, Menengah (UMKM) dan Usaha Besar. Dinas Koperasi Usaha Kecil dan Menengah Provinsi Jawa Timur, Surabaya.

Dinkop (Dinas Koperasi) Provinsi Jatim. 2014. Perkembangan Data Usaha Mikro, Kecil, Menengah (UMKM) dan Usaha Besar. Dinas Koperasi Usaha Kecil dan Menengah Provinsi Jawa Timur, Surabaya

Euis, S., Hubeis, S., dan Maulana, A. 2014. Analisis model bisnis pada KNM fish farm dengan pendekatan business model canvas (BMC). Jurnal Sosek KP, 9 (2): 185-194.

Moleong, L.J. 2012. Metodologi Penelitian Kualitatif. PT Remaja Rosdakarya, Bandung.

Osterwalder, Alexander, \& Pigneur, Yves. 2010. Business Model Generation . John Wiley \& Sons, Inc., Hoboken, New Jersey.

Permadi, B., Nurmalina, R., dan Kirbrandoko. 2016. Analisis Pengembangan Model Bisnis Kanvas CV Kandura Keramik Bandung. Jurnal Aplikasi Manajemen (JAM), 14 (1): 88-97.

Rainaldo M., Wibawa, B.M., Rahmawati, Y. 2017. Analisis business model canvas pada operator jasa online ride-sharing (Studi kasus Uber di Indonesia). Jurnal Sains dan Seni ITS, 6 (2): 235-239.
Rukka, M.R., Busthanul, N., dan Fatonny, N. 2018. Strategi pengembangan bisnis dengan pendekatan busines model kanvas (Studi Kasus Pada CV. OAG di Kota Makasar, Sulawesi Selatan). Jurnal Sosial Ekonomi Pertanian, 14 (1) : 41-54. 